Fenyves, Katalin. "Fischer, Wladimir, Waltraud Heindl, Alexandra Millner, Wolfgang Müller-Funk, eds. 2010. Grenzen und Räume in Österreich-Ungarn 1867-1918. Kulturwissenschaftliche Annäherungen (Borders and Spaces in Austria-Hungary 1867-1918: Cultural Investigations and Evaluations." Hungarian Cultural Studies. e-Journal of the American Hungarian Educators Association, Volume 7 (2014): http://ahea.pitt.edu DOI: 10.5195/ahea.2014.169

\title{
Fischer, Wladimir, Waltraud Heindl, Alexandra Millner, Wolfgang Müller-Funk, eds. 2010. Grenzen und Räume in Österreich-Ungarn 1867-1918. Kulturwissenschaftliche Annäherungen (Borders and Spaces in Austria-Hungary 1867-1918: Cultural Investigations and Evaluations). Tübingen: Francke Verlag. 409 pp.
}

\section{Reviewed by Katalin Fenyves, Budapest College of Communication and Business}

Borders and Spaces in Austria-Hungary 1867-1918 is the last in a series of five volumes presenting the results of two international research projects that offer new approaches for the study of the Habsburg Empire. The two projects: "Dominance, Ethnic Differentiation, and Literariness" and "Centers/Peripheries - Cultures and Dominance in the Austro-Hungarian Monarchy 1866-1914," were launched at the beginning of the millennium with the aim of examining the Habsburg Monarchy through the lens of postcolonial theories. Following the programmatic first volume titled Kakanien Revisited (ed. Wolfgang Müller-Funk et al.; Tübingen: Francke Verlag, 2002), four others followed, culminating with the present volume; in addition, a working platform for interdisciplinary studies and networking carrying the same title is still active (http://www.kakanien.ac.at/).

According to Wolfgang Müller-Funk, the project leader, the main topics of the present tome were translation, performance, and space, all with the intent of providing a firm theoretical and methodological foundation for the examination and analysis of these cultural manifestations. Culture, in this case, is understood as a juncture of symbolic forms, fields, and practices. By choosing "borders and spaces" as leading concepts for their inquiries, the authors, who come from various disciplines - like history, ethnology and literature - also meant to use metaphoric borders and spaces to transgress the symbolic boundaries of their discrete fields of research.

Led by these intentions, the volume editors arranged its fifteen articles in telling yet somewhat loosely defined chapters such as: "Approaches;" "Symbolically Constructed Borders;" "Presence of Migrant People;" "Space and Difference: Gender, Ethnos, Class;" "Ethnographic Knowledge and Difference;" and "Systems of Power and Regimes of Gaze: Bosnia-Herzegovina and Montenegro as Peripheries of the Empire." Some of these articles are theoretical while others are specific case studies, and though they differ in length and approach they are still united by their objective of interpreting the bygone Habsburg Monarchy as a concrete geographical, political, social and common (meaning shared by many) cultural space. Of the fifteen articles, six deal or relate to Hungarian issues due to their setting, protagonists, or authors; e.g., the last contribution is a fictional text written by the Hungarian writer László Márton (b. 1959), whose hero is the Austrian artist Alfred Kubin (1877-1959).

$(\mathrm{cc}) \mathrm{BY}$

ULIS D-Serle 
Fenyves, Katalin. "Fischer, Wladimir, Waltraud Heindl, Alexandra Millner, Wolfgang Müller-Funk, eds. 2010. Grenzen und Räume in Österreich-Ungarn 1867-1918. Kulturwissenschaftliche Annäherungen (Borders and Spaces in Austria-Hungary 1867-1918: Cultural Investigations and Evaluations." Hungarian Cultural Studies. e-Journal of the American Hungarian Educators Association, Volume 7 (2014): http://ahea.pitt.edu DOI: 10.5195/ahea.2014.169

In his essay "Jesenice und Zemplén: Grenzen und Peripherien - Skizze zu einer Poetologie des Räumes im Kontext der Habsburger Monarchie" ['Jesenice and Zemplén: Borders and Peripheries - Sketches for a Poetology of Space in the Context of the Habsburg Monarchy'], Wolfgang Müller-Funk first gives a theoretical introduction to the use of the concept of space in contemporary cultural studies. This literary-cultural overview is then followed by two examples. The first is a short analysis of Peter Handke's novel Die Wiederholung [The Repetition] (Frankfurt am Main: Suhrkamp Verlag, 1986) as a quest in a bygone time and place. The site in question is the Slovenian border-town Jesenice that ceased to belong to Austria as of 1918, and where the narrator now returns after years of absence hoping to find his brother with whom he lost contact. The other example is a short story by the Hungarian writer Kálmán Mikszáth (18471910), translated into German as "Das Geschäft des Grafen Kozsibrowszky" ["Count Kozsibrowszky's Deal"] (in: Andreas Oplatka, ed., Ungarische Erzähler; Zürich: Manesse, 1974, 129-131.). In this part of his article, Müller-Funk implements many of the analytical concepts that he presented in the introduction, thus turning this charming provincial tale into a confrontation site among ever changing peripheries and centers, or into a "carnival of cultures" in which the smart Count takes advantage of his knowledge of the "Other" (e.g., a Prussian Baron) but is eventually defeated by a young woman who turns out to be shrewder than himself.

The longest and from a Hungarian studies perspective most interesting article in the collection is Edit Király's "Der Kongo fließt durch Ungarn - Literarische Grenzinszenierungen am Beispiel der Donau" ["The Congo River runs through Hungary - the Danube as an Example of Borders Set by Literature"]. Király's sophisticated analysis deals with both real and symbolic spaces that were held, lost and regained before and after 1918 by the German minority in Hungary, especially in the Bánát region at the south-eastern part of the country, as depicted by three Swabian writers: the "Heimatautor" Adam Müller-Guttenbrunn (1852-1923), the extremely popular novelist and press publisher Ferenc Herczeg (1863-1954), and the less known Károly Molter (1890-1981). Looking at the Danube as a key element in the scenery of these nationalist constructions, Király gives a thorough and excellent overview of the self-perception and self-fashioning of the German minority in Hungary, namely, their strategies of acculturation, assimilation, and dissimilation. These strategies show astonishing parallels with similar endeavors of the Jewish minority in Hungary, though this comparison has yet to be further developed to enable a deeper insight into the processes promoting or hampering cultural homogenization of Austro-Hungarian or other minorities.

Other contributors likewise deal with Hungarian borders and spaces: Margit Feischmidt introduces her readers to the concurring claims of Hungarians and other nationalities (Romanians, Ruthenians, and Serbs) for places of collective national memory in the multi-ethnic areas of the past Monarchy, while Éva Kovács tries to identify possible reasons other than the Holocaust for emigration in the life stories of two Jewish émigrés born in Hungary and presently living in Vienna and one that was born in Transylvania and lives in Budapest. Alexandra Millner analyses a novelette titled Die Zigeunerin [The Gypsy Woman; Wien: Konegen, 1885] written by the Austrian Bánát-born writer Marie Eugenie delle Grazie (1864-1931). Millner traces the symbolic meaning of the Hungarian puszta [desert] and the socially constructed image of the Gypsy (male and female) in Grazie's novelette. Birgitta Bader-Zaar raises vital and relevant questions concerning the spatial distribution of the presence of women in the Habsburg Empire, meaning in its public as opposed to private and geographical as opposed to territorial spaces. 
Fenyves, Katalin. "Fischer, Wladimir, Waltraud Heindl, Alexandra Millner, Wolfgang Müller-Funk, eds. 2010. Grenzen und Räume in Österreich-Ungarn 1867-1918. Kulturwissenschaftliche Annäherungen (Borders and Spaces in Austria-Hungary 1867-1918: Cultural Investigations and Evaluations." Hungarian Cultural Studies. e-Journal of the American Hungarian Educators Association, Volume 7 (2014): http://ahea.pitt.edu DOI: 10.5195/ahea.2014.169

Bader-Zaar connects her findings to the women's national and ethnic identities and to their experiences of borders and mobility before and after World War I, which she sees as a point of change considering the women's previous construction of female identity and concepts of space including their movement in it.

While interesting in itself, the readers of this volume may benefit from reading it along with or following the other four volumes in this series (2004, 2006, 2006, 2008), and the tomes of another series entitled Gedächtnis - Erinnerung - Identität [Remembrance - Memory Identity], which present the results of a similar research project lead by Moritz Csáky. In the volume at hand, as in the other four, the main achievement is its broadening of horizons beyond existing academic attitudes. Of likewise special importance is the increase in the attention given in it to peripheries and other formerly neglected topoi and topics, as well as to inter- or transdisciplinary perspectives. There is only one problem concerning these volumes and that is their inaccessibility. Not even the present reviewer could get a printed review copy of Grenzen und Räume, whereas the other volumes are already out of print. Given the voluminous intellectual effort invested in them and their unequivocal accomplishment, for sure, these publications should be more easily attained, read, taught, and discussed. At best, they should be presented in the border-less space of the Internet. 